\title{
Main Barriers to ICT Teacher Training and Disability
}

\author{
Marta Montenegro Rueda * \\ University of Seville \\ José Fernández Cerero \\ University of Seville \\ *Corresponding Author: mmontenegro1@us.es \\ Received : $\quad$ 03.07.2019 \\ Revision Requested: 09.08.2019 \\ Accepted : $\quad 12.09 .2019$
}

How to cite this paper: Montenegro Rueda, M., \& Fernández Cerero, J. (2019). Main barriers to ICT teacher training and disability. Research in Social Sciences and Technology, 4 (2), 96-114.

\begin{abstract}
From the earliest ages, the commitment to an inclusive education needs the impulse of an educational system that opens its schools to all students. This reality would not be possible today without taking into account the educational support provided by Information and Communication Technologies (ICT) to the inclusive process, since they constitute the scaffolding that will allow participation and the realization of tasks adjusted to the possibilities and interests of the people. In the process of integration of ICT in the classroom, teachers are a key element since, as has been shown in numerous studies, one of the critical factors for the success of educational systems is the existence of trained, motivated teachers. The purpose is to know the main barriers or obstacles for the development of teacher training plans in ICT for people with disabilities, as well as the priority aspects for training. In the empirical part of the study, 241 interviews with professionals from the Spanish educational sector (members of management teams, ICT coordinators, directors and technological advisors of teacher training centers) were analyzed. Among the conclusions, we can highlight that the main barriers that hinder the implementation of ICT training activities and disability in most of the autonomous communities are determined in the first place by economic factors, lack of time, and teachers' attitude. The conclusions of the study make it necessary to adopt important measures in the initial training of teachers in order to be trained in the incorporation and appropriate use of ICT in teaching people with different types of disabilities, especially taking into account that the reality that we face every time has more innovative and enriching technological tools that offer us a wide range of applications and adequate tools for this purpose.
\end{abstract}

Keywords: Information and Communication Technologies, disability, teacher training, Inclusion. 
Montenegro Rueda \& Fernández Cerero. Main Barriers to ICT Teacher Training and Disability

\section{Introduction}

This article is part of a larger research project entitled "Diagnosis and teacher training for the incorporation of ICT in students with functional diversity," funded within the framework of the State Development Plan of Scientific and Technical Research of Excellence 2013-2016 (DIFOTICYD EDU2016 75232-P).

At present, despite the evidence of the existence of progress in political and normative matters that has allowed to dignify people with disabilities, in the plane of action, the processes of exclusion and inclusion are still visible, showing the difficulties and problems that are still present in the concrete process of full participation.

From the earliest ages, the commitment to an inclusive education needs the impulse of an educational system that opens its schools to all students and ensures to each of them a teaching capable of addressing existing differences. This reality would not be possible today without taking into account the educational support provided by Information and Communication Technologies (ICT) to the inclusive process, since they constitute the scaffolding that will allow participation and the realization of tasks adjusted to the possibilities and interests of the people.

It is in this process of integration of ICT in the classroom where the teacher is configured as the key element. As has been shown in numerous studies, one of the critical factors of the success of education systems is the existence of trained teachers, motivated and involved (Mourshed, Chijioke, \& Barber, 2010). In this line, the McKinsey Report, based on the comparison of the 10 best education systems in the world (Finland, South Korea, Japan, or Canada), highlights that the educational level of a country depends on training, motivation, and lifelong learning of their teachers. Training that passes inexorably for its ability to use ICT, acquiring the knowledge and skills necessary to use them as a resource to bring the teaching-learning processes to all students, including those with special educational needs. For this reason, the different educational administrations have become the acquisition of competences by teachers in ICT. These training policies have been translated into training plans that have been aimed at two aspects (Condie \& Munro, 2007): the first is the initial teacher training, which is usually included in the curriculum a mandatory component in relation to ICT, and the second aspect is that which is aimed at the professional development of the teaching staff, offered as continuous training by the different educational administrations. So, by way of example, in the Andalusian context, the Ministry of Education of the Junta de Andalucía has proposed the "Plan de Éxito Educativo 2016-2020" where a continuous commitment is made by Information and Communication Technologies (ICT) and Learning and Knowledge Technologies (TAC), through the use of ICT and TACs within the framework of the Digital Strategy Plan in Education in Andalusia. 
Montenegro Rueda \& Fernández Cerero. Main Barriers to ICT Teacher Training and Disability

The work we present focuses on the field of continuing education of teachers, and its purpose is to know the main barriers or obstacles for the development of teacher training plans in ICT for people with disabilities, as well as the priority aspects for training.

We believe that this study is important for several reasons. First of all, despite the fact that the line of research on ICT teacher education has been developing for more than two decades, there are still very few studies on training in ICT especially for people with disabilities. We think that an inclusive school should try to eliminate or minimize the barriers that limit the correct learning of its students, with special attention to the most vulnerable. A second reason is due to social aspects, where the processes of discrimination and social exclusion in the population with disabilities are of special concern in families, educational centers, town halls, and other institutions with an impact on citizen education. Lastly, it is important to pay attention to the factors of efficiency and effectiveness of pedagogical practices with ICT, since they increase communication and enhance the abilities of people with disabilities, favoring the reduction of their limitations.

In short, this work is interesting, in addition, because it allows the analysis not only of the training of teachers in ICT in primary education, but it is also able to find evidence to argue the existence of factors favoring learning with ICT, which enhance the development of good educational practices.

\section{Research questions}

Based on this context, we have considered the following research questions:

- What are the main barriers or obstacles for the development of ICT teacher training plans for people with disabilities?

- What aspects are considered priorities in the training of primary education teachers in relation to ICT and disability?

\section{Background}

The path for the integration of ICT in education has not been easy, and its maximum potential has not been reached, in the same way that pedagogical thinking has not progressed in parallel with technological advances, since these in the field of inclusive education in developed countries is very slow. One of the most noteworthy conclusions of recent studies in our context is that, despite the increase in the availability of technological resources in schools, the pedagogical practice of teachers in the classroom does not necessarily imply a substantive modification of the traditional teaching model (Area, 2008; Area, Cepeda, González, \& Sanabria, 2010). It is for this reason that there is the need for teachers to acquire skills and abilities related to the use of ICT, among other reasons, due to the lack of training, a variable that continues to be one of the factors that limit the use of ICT in the inclusive classroom. 
Montenegro Rueda \& Fernández Cerero. Main Barriers to ICT Teacher Training and Disability

The use of technology in education plays a particularly important role in allowing the development of the flexible curriculum and helping students with disabilities to participate as equals in the learning experience, helping to prepare them for lifelong learning, fun, and learning outside of school (Panzavolta \& Lotti, 2012).

In the international arena, there are numerous publications and research that show the importance of the integration of technology to improve student learning. Now, if we place ourselves in the field of disability, we can see that there are few studies that place special emphasis on the potential of ICT in students with functional diversity due to disability (Alper \& Goggin, 2017; Istenic \& Bagon, 2014; Khetarpal, 2014; Ramos \& Andrade, 2016; Shih et al., 2011; Turner-Cmuchal \& Aitken, 2016; Wallace \& Georgina, 2014).

Although ICT can be an effective instrument to improve the education of all students, it is necessary that it entails a transformation of teaching activities, because the students' learning is related to the quality of the practices in which they participate in the classroom (Coll, Mauri, \& Onrubia, 2008). Of all the factors that can affect this transformation, there is one that exerts a great influence: the degree of technological training of teachers. In this sense, and internationally, we can also highlight the scarcity of those studies aimed at teacher training to successfully teach ICT, in the framework of disability (Altinay \& Altinay, 2015; Liu, 2011; Vladimirovna \& Sergeevna, 2015; Yusof et al., 2014). In all of them, the lack of teacher training in this area is evident. Authors such as Scolartic (2015) go even further and highlight the importance of the pedagogical component over the technological, which leads us to infer that there is a direct and negative relationship in the performance of the teacher, since at higher levels of complexity, there is less evidence of competency.

In the Spanish context, the volume of production of works related to the problem of ICT training of teachers and the skills they need to use it is abundant, as has been shown in recent years (Fernández Batanero \& Bermejo, 2012; Ortiz, Almazán, Peñaherrera, \& Cachón, 2014; Rangel \& Peñalosa, 2013; Rosario \& Vázquez, 2012; Terigi, 2013). The studies carried out in order to know the digital competence of teachers to facilitate the integration of ICT in the classroom suggest that although teachers have a certain mastery of technical aspects, they do not use technology for teaching practice since this requires skills or higher level capabilities (Prendes \& Gutiérrez, 2013), conclusions coinciding with those of Scolartic (2015). So, if we talk about the ICT competences necessary to use them with people with functional diversity due to disability, we can check the low volume of existing jobs, and they also highlight the lack of training and knowledge that teachers have regarding the different types of technologies that can be used with these people, the possibilities they offer, and the functions for which they can be used (Baytak et al., 2011; Molina, Pérez, \& Antiñolo, 2012; Roig, Ferrández, Rodríguez-Cano, \& Crespo, 2012; Tello \& Cascales, 2015; Toledo \& Llorente Cejudo, 2016). 
This lack of ICT training is one of the main obstacles or barriers that the teacher finds when dealing with students with disabilities in the classroom. Among the barriers or obstacles that teachers find for their training, we find lack of training and financial support, as stated by Silva and Austillo (2012). Likewise, the study also includes the lack of recognition and incentive to teachers. Another barrier to highlight is the lack of time, which hinders the planning of educational work (Barrantes, Casas, \& Luengo, 2011). On the other hand, Ramírez, Cañedo, and Clemente (2011) show that the attitude of teachers towards ICT also constitutes a barrier to teacher training.

Aspects that have a negative impact on the teaching-learning processes with ICT make it impossible to make information more accessible and enhance people's abilities, in the case of students with disabilities, helping their difficulties to be alleviated and, in some cases, their limitations reduced to a minimum (Homero, Tejedor, \& Calvo, 2017).

For Cullen and Alber-Morgan (2015), the daily use of different technologies by disabled students has positive effects on their learning, making them independent. Therefore, when technology is properly integrated in the classroom, students, with the disability they have, will have multiple means to train and achieve an adequate academic education. That is why teachers not only have to have theoretical knowledge of the subjects taught but also of the adapted resources that exist and are necessary to teach the disabled student.

There is no doubt that the benefits of ICT to students with disabilities are many and very diverse. In particular, they can facilitate access to all types of information in an easier and more comfortable way; favor the autonomy of students, being able to adapt to the needs and demands of each student in a personalized way; favor the synchronous and asynchronous communication of these students with the rest of classmates and the teaching staff; help to adapt the environment; improve cognitive development thanks to the activities that can be done; save time for acquiring skills and abilities; favor the diagnosis of the student; support a multisensory communication and training model; encourage individualized training, as students can move at their own pace, which is extremely important for these subjects; favor the development of the autonomy and independence of the people; avoid marginalization and the digital divide, which introduces being devoid of using the tools of development of the knowledge society; facilitate the socio-labor insertion of the student with specific difficulties; provide moments of leisure; save time for acquiring skills and abilities; allow the exercises that the students must carry out to be executed and repeated with minimum efforts so that the students acquire the competences, attitudes, and capacities; encourage the approach of these people to the scientific and cultural world; and be excellent simulators (Toledo, 2013). 


\section{Method}

The purpose of the study was to learn about the main barriers encountered by primary school directors and advisors in the Spanish state for the development of ICT training plans for people with disabilities, as well as aspects that are considered a priority in such training.

\section{Research design}

The research design is situated from a descriptive ethnographic research perspective, from which the data collection and analysis approach has been defined from qualitative techniques. The technique used to collect the information was the semi-structured interview prepared ad hoc.

\section{Instruments}

For the validation of the interviews, it was decided to apply the expert judgment technique, this being done through a document attached to the interview, with a series of open questions that were delivered to eight specialists in the area from different Spanish universities. In the validation of the interview protocol, the Delphi method was used because it is based on the recognition of the superiority of group judgment over the individual trial (Linstone \& Turoff, 1975).

The categories of interviews have revolved around: sociodemographic aspects (type of center, community / autonomous city, province, position held, sex and seniority in office); concept of functional diversity; disability concept; ICT benefits for people with disabilities; teacher awareness and preparation; development of training experiences; promotion of training; barriers to the development of training plans; and priority in training. For content analysis, the following phases have been followed: preanalysis, categorical system formation, coding and analysis and interpretation, using a computer tool that facilitates the qualitative data analysis, NVivo 11.

Finally, it is worth mentioning that the elaboration of the categories and the decision to take the answers of the interviewees as correct or incorrect have been subject to concordance and reliability criteria. That is to say, the analysis carried out, both for the process of construction of the system of categories (agreement between coders), and for the moment in which the coders have made use of this system of categories (reliability), has resulted in a coefficient excellent kappas above 0.75 (Fleiss, 1981).

The categorical system used for the analysis of the interviews, in the two aspects shown in this article, has been as follows (Table 1 ): 
Table 1.

Categorical System

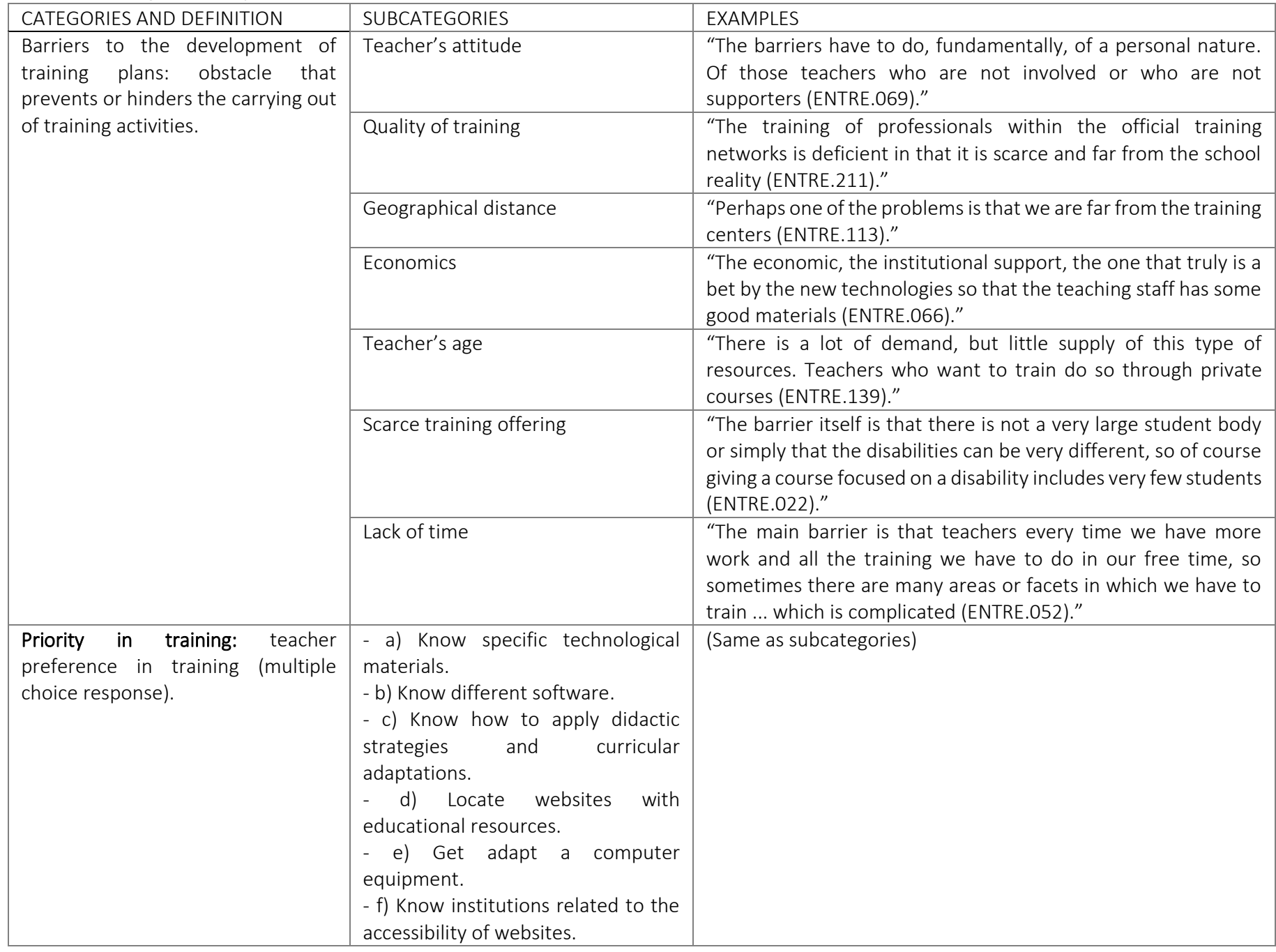

\section{Sample}

In this research, 241 professionals from the education sector participated. For the selection of the sample, a probabilistic sampling was chosen, since the objective of the study is to estimate what is true for a population from a group of participants. Specifically, it has been done by groups in which natural group units have been identified, in our case, autonomous communities / cities and types of centers. Once the grouping has been made, the subjects have been selected at random, in such a way that all of them have had the same probability of being chosen (principle of equiprobability) (McMillan \& Schumacher, 2005, p. 135-140). 
Therefore, the object of the study has been educational centers of public, private and concerted ownership, as well as teacher training centers (CEP hereafter), located in 19 communities and autonomous cities of Spain.

\section{Table 2.}

Distribution communities / autonomous cities and type of center.

\begin{tabular}{|c|c|c|c|c|c|}
\hline & CEP & Public & Private & Concerted & TOTAL \\
\hline Andalusia & 3 & 7 & 3 & 3 & 16 \\
\hline Aragon & 3 & 6 & 2 & 2 & 13 \\
\hline Asturias & 2 & 7 & 2 & 2 & 13 \\
\hline Cantabria & 2 & 6 & 2 & 3 & 13 \\
\hline Castilla La Mancha & 2 & 6 & 6 & 0 & 14 \\
\hline Castilla y León & 2 & 7 & 3 & 3 & 15 \\
\hline Catalonia & 3 & 7 & 4 & 3 & 17 \\
\hline Ceuta & 0 & 2 & 3 & 0 & 5 \\
\hline Extremadura & 3 & 6 & 2 & 2 & 13 \\
\hline Galicia & 2 & 6 & 2 & 3 & 13 \\
\hline Balearic Island & 2 & 6 & 2 & 2 & 12 \\
\hline Canary Island & 2 & 7 & 1 & 2 & 12 \\
\hline La Rioja & 1 & 6 & 5 & 0 & 12 \\
\hline Madrid & 3 & 6 & 3 & 3 & 15 \\
\hline Melilla & 1 & 3 & 1 & 1 & 6 \\
\hline Murcia & 1 & 6 & 2 & 2 & 11 \\
\hline Navarra & 2 & 7 & 3 & 1 & 13 \\
\hline Basque Country & 2 & 7 & 3 & 2 & 14 \\
\hline Valencia & 2 & 7 & 2 & 3 & 14 \\
\hline TOTAL & 38 & 115 & 51 & 37 & 241 \\
\hline
\end{tabular}

The distribution of the interviews carried out was as follows: 174 members of the management team, 29 ICT coordinators, 23 directors of teacher training centers (CEP), and 15 technology advisers of teacher training centers (CEP). All the interviews have been done personally.

Of the total sample, $53.11 \%$ corresponds to directors of educational centers or training centers ( $N=128), 25.31 \%$ refers to heads of studies $(N=61)$, and $21.58 \%$ to ICT coordinators of educational centers or consultants of training centers $(N=52) ; 43.9 \%$ of the interviewees are men and $56 \%$ are women. 


\section{Results}

Based on the empirical basis of the opinions of the informants, the following results have been obtained.

\section{Barriers to the development of training plans}

Once verified that the centers ensure that the training is offered and promoted through courses, working groups, projects, meetings and/or seminars (79.69\%), but that there are not really enough training experiences $(66.8 \%)$, it is necessary to know what are the barriers or impediments that hinder the development of these training activities.

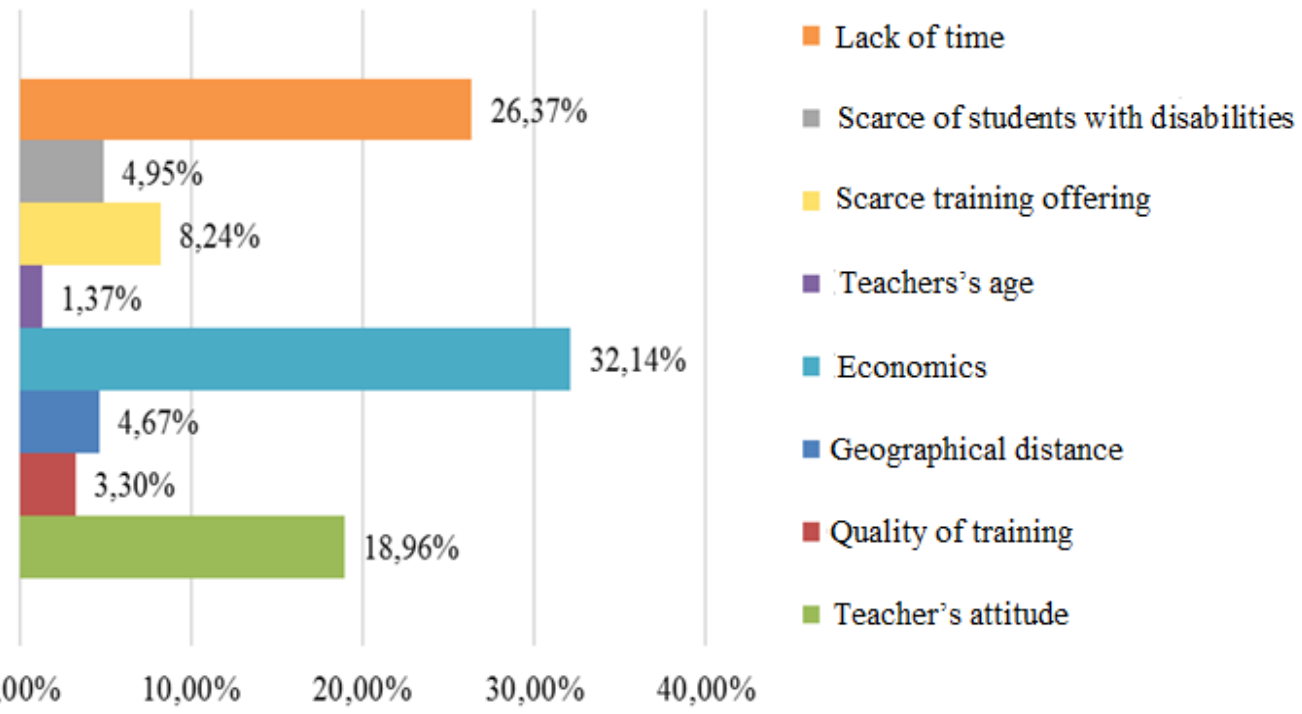

Figure 1. Main obstacles to carry out training activities.

Figure 1 shows in percentages the main barriers that, according to the interviewees, hinder the realization of training activities. The barriers that have a higher percentage of appearance are:

- $\quad$ The one related to "economic" factors (32.14\%). In this case, highlights such as:

"The first barrier I think is the economic one. If you do not have devices, or mobiles, or computers to do tasks, you can hardly use them in the classroom. Moreover, some teachers use personal devices in the classroom (ENTRE.122)."

"Well, the main barrier is the material resources we have, the budgets. Every year the center demands training courses, among them on functional diversity through this training plan and we find ourselves with the difficulty that the budgets do not arrive through the CEP and others. (ENTRE.227)."

- $\quad$ The one referred to "lack of time" (26.37\%). The interviewees stated that: 
"Barriers is the availability of teachers or time, which does not always have time. Many times the teachers if they want, but do not have the time, that is, there are no times in the centers for this training, we do not have a timetable, especially in primary schools (ENTRE.013)."

"The main barrier is the lack of time not only to carry out the training, but to prepare the sessions in which we can incorporate the acquired knowledge (ENTRE.154)."

- The one referring to "teacher's attitude" (18.96\%). In this sense, the interviewees hold demonstrations in relation to an advanced age for training and little awareness of the importance of such learning: "Discouragement by some of the teachers because they are older, they see that their retirement is near and all this seems very complicated (ENTRE.037)."

"The main barrier is teacher awareness. Teachers are often aware of the problem they have, but at the same time they are selfish when it comes to demanding training actions (ENTRE.225)."

It is also interesting to note that the emergence of barriers related to factors such as "economic" and "lack of time" is shared by many autonomous communities/cities with the exception of Galicia and the Balearic Islands, which consider that the main obstacle is "teacher's attitude," and La Rioja that highlights as a barrier the "scarce training offering," that is, justify that the problem is that there is a limit of places in the courses offered.

"Many times it is the limitation in places. The city takes a course with 20 or 30 seats for all teachers, and many times, many people stay out. That is the only barrier you can find, the limitation of places because we as a concerted center treat us differently than those of the public (ENTRE.042)."

\section{BARRIERS}

Economics ack of time
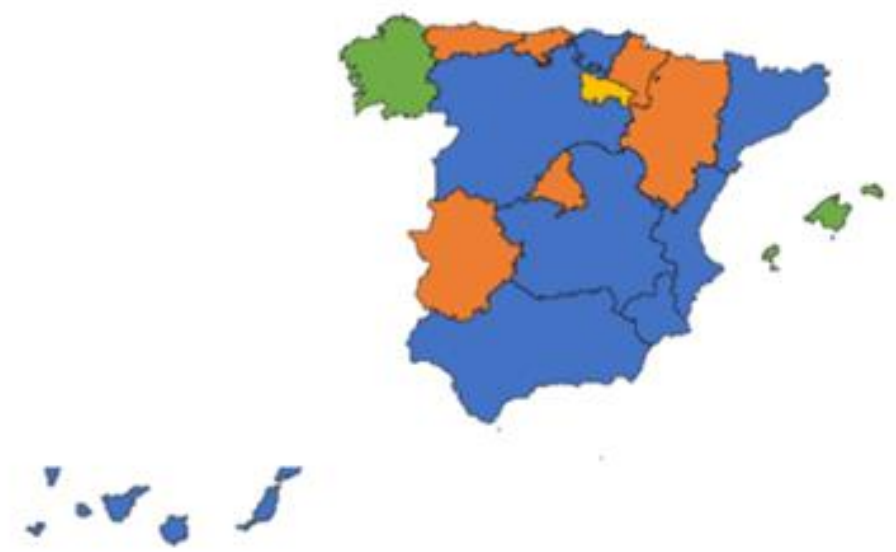

Figure 2. Obstacles by communities.

Finally, according to Table 3, we can see that CEIPs are the ones that claim to find a higher percentage of barriers to carry out training activities. The data could justify the results obtained 
in the categories related to teacher training. It turns out that the CEIPs are the ones that offer the most, but the ones that experience less training. This fact is striking and the explanation would be given by the high number of barriers or obstacles that are found to carry them out.

These barriers are also present in the rest of the centers; therefore, it is necessary to propose a training activity that adapts to the teaching staff and does not take into account factors such as those dealt with in this category that hinder their development.

\section{Table 3.}

Barriers by institutions.

\begin{tabular}{|l|l|l|l|l|}
\cline { 2 - 5 } \multicolumn{1}{c|}{} & Public & Concerted & Private & CEP \\
\hline Teacher's attitude & $46.38 \%$ & $14.49 \%$ & $15.94 \%$ & $23.19 \%$ \\
\hline Quality of training & $58.33 \%$ & $16.67 \%$ & $16.67 \%$ & $8.33 \%$ \\
\hline Geographical distance & $64.71 \%$ & $5.88 \%$ & $29.41 \%$ & $0 \%$ \\
\hline Economics & $42.86 \%$ & $15.97 \%$ & $17.65 \%$ & $23.53 \%$ \\
\hline Teacher's age & $60 \%$ & $0 \%$ & $40 \%$ & $0 \%$ \\
\hline Scarce training offerings & $43.33 \%$ & $26.67 \%$ & $20 \%$ & $10 \%$ \\
\hline Scarce of students with disabilities & $44.44 \%$ & $16.67 \%$ & $16.67 \%$ & $22.22 \%$ \\
\hline Lack of time & $55.67 \%$ & $24.75 \%$ & $14.43 \%$ & $5.15 \%$ \\
\hline
\end{tabular}

\section{Priority in training}

In the next category, several statements are presented that deal with aspects that should include training activities aimed at primary school teachers. Participants have had the opportunity to choose the three statements they consider to be a priority in teacher training.

Among the most relevant results, the interviewees consider that training activities facilitate the task of applying curricular strategies and didactic adaptations supported by ICT (86.72\%), which favor being able to know specific technological materials for students with disabilities (61. 83\%), to locate websites with educational resources for people with disabilities (41.91\%), as well as to adapt a computer equipment to the educational needs of any person with a disability (41.91\%).

It is also considered appropriate to emphasize that the statement "know institutions related to the accessibility of websites" is the one with the lowest percentage of choice (18.67\%). The result obtained is striking because accessibility was the subcategory that reached a high frequency of appearance in the category related to the "benefits provided by Information and Communication Technologies (ICT) to people with disabilities." 


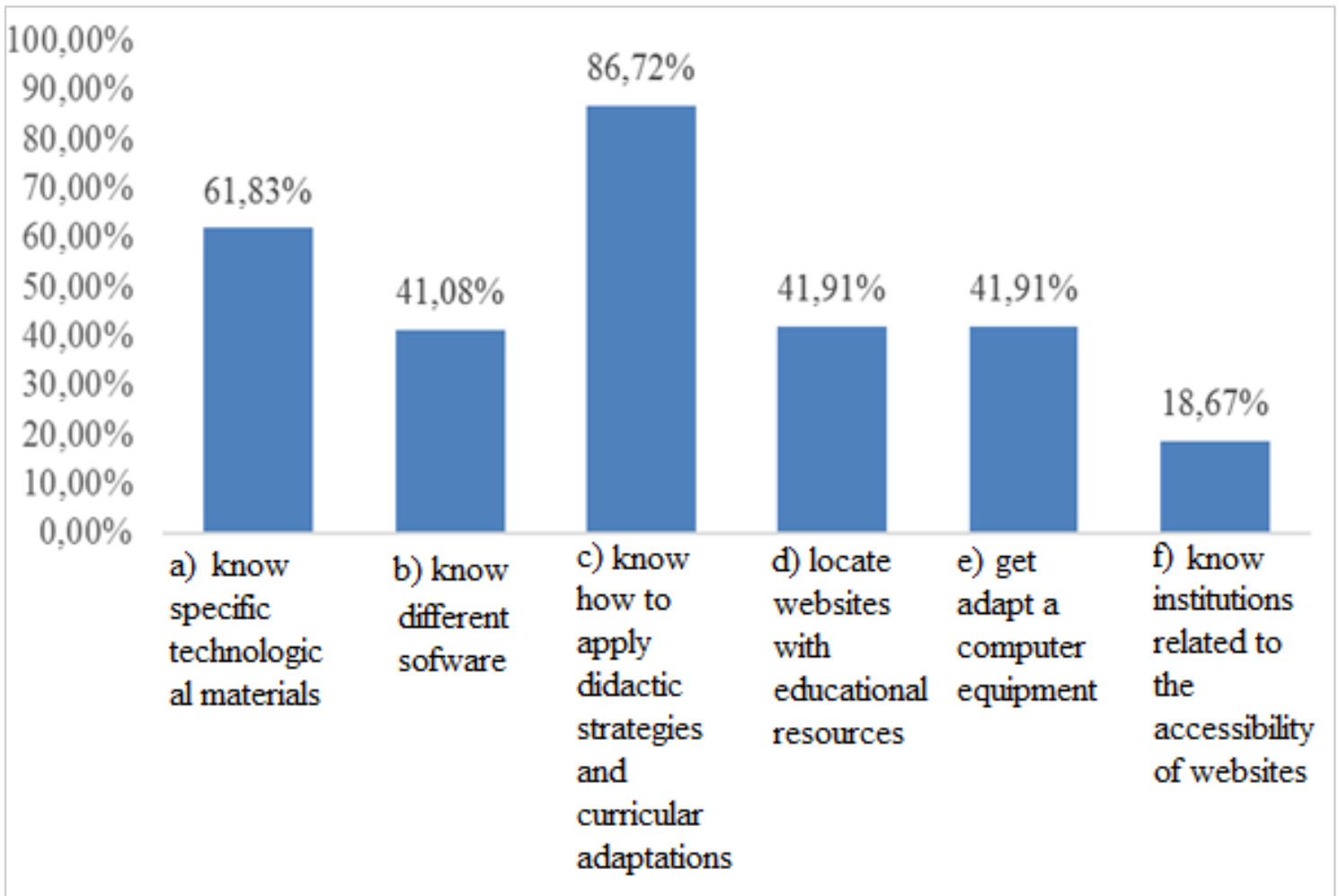

Figure 3. Aspects that training activities should contemplate.

Likewise, the choice of those elements that should be included in teacher training varies according to autonomous communities or cities. The statement "know how to apply teaching strategies and curricular adaptations" has once again been shared by many autonomous communities/cities with the exception of Asturias, La Rioja and Murcia, which attribute greater importance to the knowledge of specific technological materials, and Ceuta and Melilla, where they consider necessary that teacher training includes knowledge of different specific software to be used with students with functional diversity. 


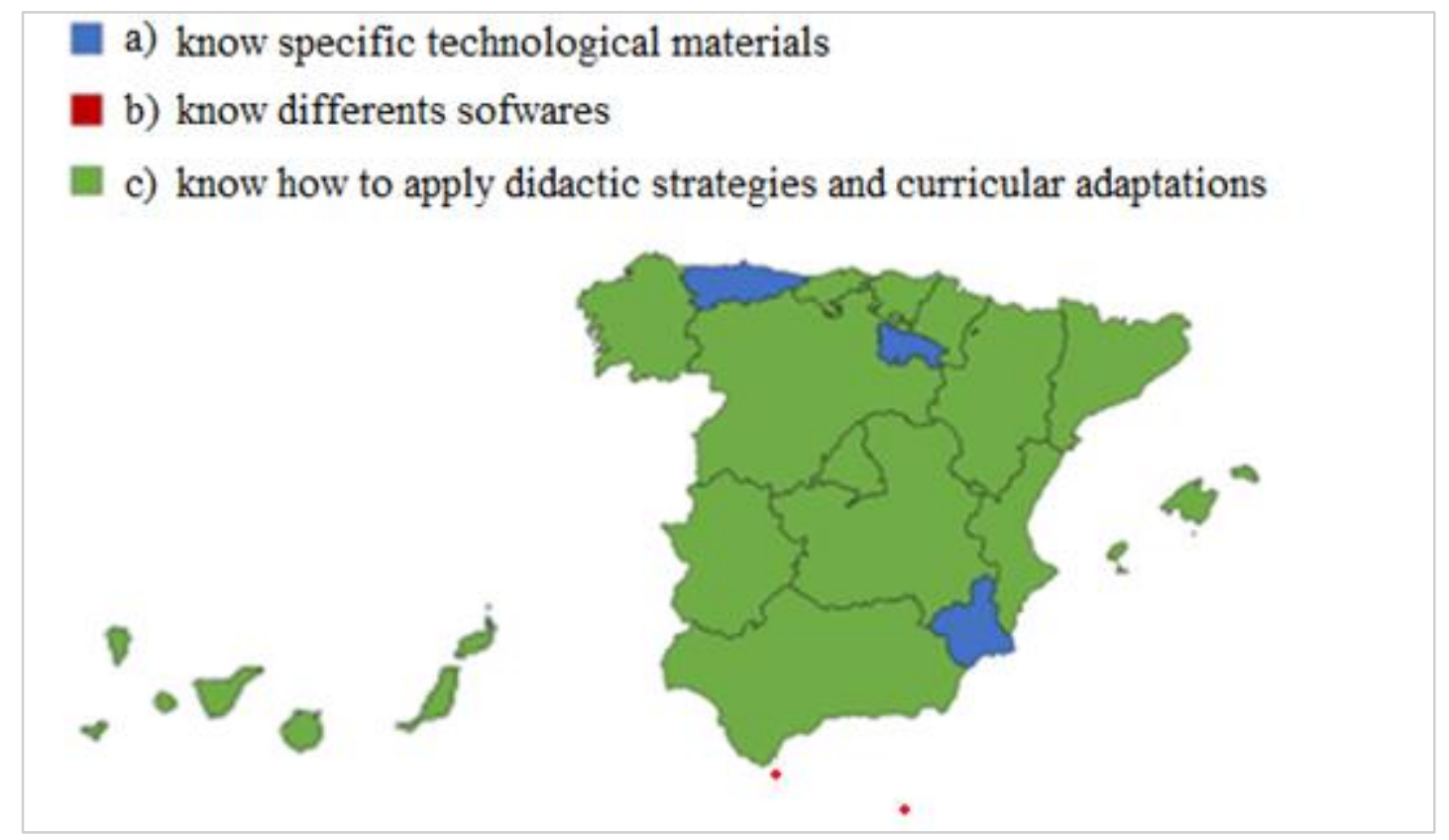

Figure 4. Training activities by communities.

Finally, we would like to add that depending on the type of center, the results do not allow us to establish relevant differences, since the percentage of choice of the statements has remained fairly similar in each of these. Despite this, the result shows the need for a training activity that includes all the elements (materials, software, application of strategies and adaptations, websites, adaptation of computer equipment, and accessible institutions). 


\begin{tabular}{|c|c|c|c|c|}
\hline \multicolumn{5}{|l|}{$60,00 \%$} \\
\hline $50,00 \%$ & & & & \\
\hline $40,00 \%$ & & & & \\
\hline $30,00 \%$ & & & & \\
\hline $20,00 \%$ & & & & \\
\hline $10,00 \%$ & & & & \\
\hline $0,00 \%$ & Público & Concertado & Privado & CEP \\
\hline $\begin{array}{l}\text { a) Know specific } \\
\text { technological materials }\end{array}$ & $44,97 \%$ & $22,82 \%$ & $15,44 \%$ & $16,78 \%$ \\
\hline b) Know different software & $50,51 \%$ & $22,22 \%$ & $16,16 \%$ & $11,11 \%$ \\
\hline $\begin{array}{l}\text { c) Know how to apply } \\
\text { didactic strategies and } \\
\text { curricular adaptations }\end{array}$ & $46,89 \%$ & $21,05 \%$ & $15,79 \%$ & $16,27 \%$ \\
\hline $\begin{array}{l}\text { d) Locate websites with } \\
\text { educational resources }\end{array}$ & $47,52 \%$ & $21,78 \%$ & $15,84 \%$ & $14,85 \%$ \\
\hline $\begin{array}{l}\text { e) Get adapt a computer } \\
\text { equipment }\end{array}$ & $52,48 \%$ & $17,82 \%$ & $12,87 \%$ & $16,83 \%$ \\
\hline $\begin{array}{l}\text { f) Know institutions } \\
\text { related to the accesibility } \\
\text { of websites }\end{array}$ & $53,33 \%$ & $15,56 \%$ & $15,56 \%$ & $15,56 \%$ \\
\hline
\end{tabular}

Figure 5. Priority in training according to the institution.

\section{Conclusions}

RQ1: What are the main barriers or obstacles for the development of ICT teacher training plans for people with disabilities?

The main barriers that hinder the implementation of ICT training activities and disability in most of the autonomous communities are determined in the first place by intrinsic factors such as: economic, time, and teacher attitude. These aspects coincide with previous studies, although those do not deal specifically with students with disabilities (Barrantes, Casas, \& Luengo, 2011; Ramírez, Cañedo, \& Clemente, 2011; Silva \& Austillo, 2012).

It is noteworthy that the Educational Centers for Early Childhood and Primary Education (CEIP) are the ones that offer the most, but at the same time they are the ones that experience less training. The cause of this is determined by factors such as the previous ones.

In public centers, the main barriers that arise are determined by "geographical distance," followed by "quality in training" and "lack of time" to complete it. On the contrary, the 
concerted centers consider the "scarce training offer" as the main barrier, followed by "lack of time." The privately owned centers consider the "economic" as the main factor.

Our study shows that the lack of training and confidence of teachers in ICTs is decisive for their commitment to them. This lack is directly related to the quality and quantity of the teacher training programs. In this sense, the autonomous community of La Rioja offers the lowest training offer in the country.

RQ2: What aspects are considered priorities in the training of primary education teachers in relation to ICT and disability?

Regarding the priority in the training, it is considered necessary that the training activities facilitate the task of applying curricular strategies and didactic adaptations supported by ICT, favor the knowledge of specific technological materials for students with disabilities, and facilitate the localization of websites with educational resources for people with disabilities. In short, it highlights the need for a training activity that includes all the elements (materials, software, application of strategies and adaptations, websites, adaptation of computer equipment, and accessible institutions).

\section{Implications}

It is necessary to adopt important measures in the initial training of teachers in order to be trained in the incorporation and appropriate use of ICT in the teaching of people with different types of disabilities, especially considering that the reality that we have every time has more innovative and enriching technological tools that offer a wide range of applications and suitable tools for this purpose. 
Montenegro Rueda \& Fernández Cerero. Main Barriers to ICT Teacher Training and Disability

\section{References}

Alper, M., \& Goggin, G. (2017). Digital technology and rights in the lives of children with disabilities. New Media and Society, 19(2), 726-740. doi:10.1177/1461444816686323

Altinay, A., \& Altinay, Z. (2015). Examination on ICT integration into special education schools for developing countries. TOJET: The Turkish Online Journal of Educational Technology, 14(3), 70-72.

Area, M. (2008). La innovación pedagógica con TIC y el desarrollo de las competencias informacionales y digitales [Pedagogical innovation with ICT and the development of information and digital competencies]. Investigación En La Escuela, (64), 5-17.

Area, M., Cepeda, O., González, D., \& Sanabria, A. (2010). Analysis of activities with ICT in secondary education classrooms. Pixel-Bit: Revista De Medios Y Educación, (38), 187199.

Barrantes, G., Casas L. M., \& Luengo, R. (2011). Perceived barriers to the integration of ICT for preschool and primary teachers in Extremadura. Pixel-Bit: Revista De Medios $Y$ Educación, (39), 83-94.

Baytak, A., Tarman, B., \& Ayas, C. (2011). Experiencing technology integration in education: Children's perceptions. International Electronic Journal of Elementary Education, 3(2), 139-151.

Coll, C., Mauri, T., \& Onrubia, J. (2008). Analyzing actual uses of ICT in formal educational contexts: A socio-cultural approach. Revista Electrónica de Investigación Educativa, 10(1)

Condie, R., Munro, B., Muir, D., \& Collins, R. (2005). The impact of ICT initiatives in Scottish schools: Phase3. Edinburg: Scottish Executive Education.

Čop, M., \& Topolovec, V. (2009). The implementation of information and communications technology in educating children with special needs. Informatologia, 42(4), 304-313.

Cullen, J. M., \& Alber-Morgan, S. R. (2015). Technology mediated self-prompting of daily living skills for adolescents and adults with disabilities: A review of the literature. Education and Training in Autism and Developmental Disabilities, 50(1), 43-55.

Fernández Batanero, J. M., \& Bermejo, B. (2012). Teachers' attitudes toward ICT in good practice teaching in schools with inclusive orientation. Enseñanza \& Teaching, 30(1), 45-61. 
Montenegro Rueda \& Fernández Cerero. Main Barriers to ICT Teacher Training and Disability

Fleiss, J. L. (1981). Statistical methods for rates and proportions. New York: John Wiley and Sons.

García-Abreu, L., \& Fernández-García, S. (2008). Procedimiento de aplicación del trabajo creativo en grupo de expertos [Procedure for the application of creative work in a group of experts]. Energética, 29(2), 46-50.

Ghaleb, A. (2014). Assistive Technology in special education and the universal design for learning. TOJET: The Turkish Online Journal of Educational Technology, 13(2), 18-23.

Homero, G., Tejedor, F. J., \& Calvo, M. I. (2017). Meta-analysis in the efect of educative software on students with special educational needs. Revista de Investigación Educativa, 35(1), 35-52.

Istenic, A., \& Bagon, S. (2014). ICT-supported learning for inclusion of people with special needs: Review of seven educational technology journals, 1970-2011. British Journal of Educational Technology, 45(2), 202-230. doi:10.1111/bjet.12086

Junta de Andalucía. (2016). Plan De Éxito Educativo 2016-2020. Sevilla: Consejería De Educación y Deporte.

Khetarpal, A. (2014). Information and communication technology (ICT) and disability. Review of Market Integration, 6(1), 96-103.

Linstone, H. A., \& Turoff, M. (1975). Introduction. In H. A. Linstone and M. Turoff (Eds.), The delphi method: Techniques and applications (pp. 3-12). Reading, PA: Addison-Wesley Publishing Company.

Liu, S. H. (2011). Un modelo multivariado de factores que influyen uso de tecnología por futuros profesores durante la práctica enseñanza [A multivariate model of factors that influence the use of technology by future teachers during teaching practice]. Tecnología Para la Educación y Sociedad, 15(4), 137-149.

Marín, V., \& Reche, E. (2012). 2.0 University: Attitudes and skills to the TIC of new students of the college of training teachers of the UCO. Pixel-Bit, Revista de Medios y Educación, 40, 197-211.

Mateo, J. (2004). La investigación ex post-facto [Ex post-facto research]. In R. Bisquerra-Alzina (Ed.), Metodología de la investigación educativa (pp. 195-230). Madrid: La Muralla. 
Montenegro Rueda \& Fernández Cerero. Main Barriers to ICT Teacher Training and Disability

McMillan, J., \& Schumacher, S. (2005). Investigación educativa [Educational investigation]. Madrid: Pearson Educación.

Molina, M. D., Pérez, A., \& Antiñolo, J. L. (2012). Las TIC en la formación inicial y en la formación permanente del profesorado de infantil y primaria [ICT in the initial formation and in the permanent formation of the teaching staff of Infantile and Primary]. Edutec, Revista Electrónica De Tecnología Educativa, 41, a211.

Morales, M., Trujillo, J. M., \& Raso, F. (2015). Perceptions about ICT's integration in the teaching learning process in the university. Píxel-Bit: Revista de Medios y Educación, 46, 103-117.

Mourshed, M., Chijioke, C., \& Barber, M. (2010). How the world's most improved school systems keep getting better. London: McKinsey \& Company.

O'Dwyer, L., \& Bernauer, J. (2014). Quantitative research for the qualitative researcher. Thousand Oaks, CA: Sage.

Ortíz, A. M., Almanzán, L., Peñaherrera, M., \& Cachón, J. (2014). ICT training of future teachers from the analysis of practice at the University of Jaen. Pixel-Bit: Revista de Medios y Educación, 44, 127-142.

Panzavolta, S., \& Lotti, P. (2012). Integrating students with special needs into mainstream classrooms: The role of ICT. Sennet Project Thematic Report No. 1.

Prendes, M. P., \& Gutiérrez, I. (2013). Technological competences of teachers in Spanish Universities. Revista De Educación, 361, 196-222. doi:10-4438/1988-592X-RE-2011361-140

Ramírez, E., Cañedo, I., \& Clemente, M. (2011). Attitudes and beliefs of secondary teachers about internet use in their classrooms. Comunicar, 19(38), 47-155.

Ramos, S. I. M., \& De Andrade, A. M. V. (2016). ICT in Portuguese reference schools for the education of blind and partially sighted students. Educación y Tecnologías de la Información, 21(3), 625-641.

Rangel, A. (2015). Digital teaching skills: A profile. Pixel-Bit: Revista de Medios y Educación, (46), 235-248.

Rangel, P., \& Peñalosa, E. (2013). Digital literacy in higher education professors:

Construction and empirical test of an assessment instrument. Pixel-Bit: Revista de Medios y Educación, (43), 9-23. 
Montenegro Rueda \& Fernández Cerero. Main Barriers to ICT Teacher Training and Disability

Roig, R., Ferrández, S., Rodríguez-Cano, C., \& Crespo, M. (2012). El uso de las TIC en el aula de educación especial percepción de los maestros [The use of ICTs in special education classroom: Teacher perception]. In J. Navarro, M. T. Fernández, F. J. Soto, and F. Tortosa (Eds.), Respuestas flexibles en contextos educativos diversos. Murcia: Consejería de Educación, Formación y Empleo.

Rosario, H., \& Vásquez, L. (2012). University professors education in the use of ICT Venezuelan public and private universities case (Carabobo U. and Metroplitana U.). Pixel-Bit: Revista de Medios y Educación, (41), 163-171.

Scolartic. (2015). Espacio social de aprendizaje, innovación y calidad educativa. Available in http://www.scolartic.com

Silva, J. E., \& Austillo, A. A. (2012). Inserción de TIC en la formación inicial docente: Barreras y oportunidades [Insertion of ICT in the initial teacher training: Barriers and opportunities]. Revista Iberoamericana de Educación, 58(4).

Tello, I., \& Cascales, A. (2015). ICT and special educational needs: Analysis of ICT skills teachers. Ried, 18(2), 355-383.

Toledo, P. (2013). Las tecnologías de la información, la comunicación y la inclusión educativa [Information technology, communication and educational inclusion]. In Nuevos escenarios digitales. Las tecnologías de la información y la comunicación aplicadas a la formación y desarrollo curricular (pp. 411-427). Madrid: Pirámide.

Toledo, P., \& Llorente Cejudo, M. C. (2016). Initial teacher training in the use of information and communications technology (ICT) for education of the disabled. Digital Education Review, 30, 123-134.

Turner-Cmuchal, M., \& Aitken, S. (2016). ICT as a tool for supporting inclusive learning opportunities. Perspectivas Internacionales Sobre La Educación Inclusiva, 8, 159-180.

Vladimirovna, S., \& Sergeevna, O. (2015). Features of the information and communication technology application by the subjects of special education. International Education Studies, 8(6), 162-170.

Wallace, T., \& Georgina, D. (2014). Preparing special education teachers to use educational technology to enhance student learning. 11th International Conference on Cognition and Exploratory Learning in Digital Age.

Yusof, A. M., Gnanamalar, E., Daniel, S., Low, W., \& Aziz, K. (2014). Teachers' perception of mobile edutainment for special needs learners: The Malaysian case. International Journal of Inclusive Education, 18(2), 234-256. 